\title{
A Centre for Ecosystem Research
}

The Institute of Ecosystem Studies (IES) was established by The New York Botanical Garden in 1983 to conduct significant, high-quality research on ecology. The programme at the Institute is strongly research-oriented, and emphasizes large-scale and long-term approaches to understanding ecosystem structure and function. The resulting knowledge will then be used to increase our understanding of the consequences of human interactions with natural ecosystems, and to provide better information for formulating important public policy than was available hitherto.

The Director, Dr Gene E. Likens, heads a research staff of sixteen PhDs at IES, where specific research interests now include nutrient cycling, landscape ecology, aquatic ecology, acid precipitation, plant-animal interactions, wildlife ecology, microbial ecology, chemical ecology, and forest ecology.

The Institute is located at the Mary Flagler Cary Arboretum in Millbrook, New York, $120 \mathrm{~km}$ to the north of New York City. The 778-ha Arboretum is topographically and ecologically diverse, and provides a wide variety of habitats for ecological study. Major habitat types include deciduous and mixed conifer forests, old fields, and wetlands. A 6-km-long section of a fourth-order trout stream flows through the Arboretum, of which much will be used for long-term ecological studies. Additional research opportunities are available at the Hubbard Brook Experimental Forest in New Hampshire, where several gauged and well- studied watersheds provide outstanding prospects for research into the biogeochemistry of forested ecosystems.

A modern, 3,150- $\mathrm{m}^{2}$ building houses offices, a library, and state-of-the-art laboratories equipped for both inorganic and organic analyses. A new dormitory and two converted houses provide both long- and short-term housing for as many as 35 visiting scientists and students. Residences are also available for sabbatical visitors. There are 20 other buildings on the property, including a field laboratory and a greenhouse-nursery complex complete with lath house and a cold-storage facility.

The Institute offers one or two summer research fellowships each year for university or college faculty members to conduct research at the Arboretum. Educational opportunities for graduate students are available through Rutgers University, Cornell University, and the Joint Program in Ecological Sciences offered by the Institute and Yale University. In addition, qualified undergraduate and graduate students may undertake research projects with staff scientists. Internships, fellowships, research assistantships, work-study, and volunteer positions, are available as well.

For further information about the Institute and its programmes, please contact the Information Office, Institute of Ecosystem Studies, The New York Botanical Garden, Mary Flagler Cary Arboretum, Box AB, Millbrook, New York 12545, USA-telephone (914) 677-5343.

\section{The Panos Institute*}

The Panos Institute is a new international organization, established in May 1986 to provide independent information on development and environment. Through accurate and objective reporting, Panos aims to crystallize the latest thinking on development issues, and provide information to those who need it in forms that can be easily assimilated and readily used.

Working in partnership with 'the media', non-governmental organizations (NGOs), aid-agencies, and governments, Panos aims to combine careful research with imaginative and forceful dissemination. It provides a link between North and South, and a bridge between the commercial media and the development community, as well as between NGOs and official agencies. In response to changed information-needs, it is extending its dissemination from the printed word to radio, television, and video broadcasting.

Panos was founded by the undersigned together with other former staff members of Earthscan, who since 1975 have earned world-wide respect from journalists, the media, NGOs, decision-makers, and donors. Panos has offices in London, England, and Washington, DC, and will shortly open an office in Paris. Panos is currently financed by the governments of the UK, Denmark, Finland, the Netherlands, Norway, and Sweden, and by the European Commission, the Norwegian Red Cross, Redd Barnat, the American Foundation for AIDS Research (AMFAR), the Benton Foundation, the Beldon Fund, the Noyes Foundation, the Carnegie Corporation of New York, and the Beijer Institute. Panos is editorially independent.

Current activities of the Panos Institute include:

- The AIDS information programme, which in 1986 published the first accessible global overview of the AIDS

\footnotetext{
* The name is derived from the ancient Greek word for a torch or shining light. - Ed.

$\dagger$ Name of the Save the Children movement in Norway.-Ed.
}

pandemic and its impact on developing countries: AIDS and the Third World. Future publications on AIDS include further dossiers and a general book to be published in 1988 .

- Publication of a popular book highlighting the lives and conditions of city children both in the Third World and the North.

- Panos Features providing articles, news stories, and short information briefs, to over 400 leading newspapers and magazines in nearly 100 countries.

- Panoscope, a bi-monthly magazine which is sent to the Panos network of over 2,000 non-governmental groups and 700 decision-makers.

- Panos Pictures, a specialist photolibrary on Third World development and environment subjects.

- Rural Electrification Programme, a two-years' study evaluating what benefits, if any, rural electrification brings to the people it is designed to help.

- The Focal Country Programme, under which information activities are focused in seven Third World countries: Kenya, Zambia, Tanzania, Bangladesh, India, Sri Lanka, and Indonesia (activities include media workshops for journalists and NGOs, feature co-syndication schemes in local languages, fellowships to journalists and NGO writers, provision of briefing material to decision-makers, and development of a radiotape/script service).

- The Sahel Programme, which is based on the successful Focal Country Programme, will work to strengthen the information capacities of media and NGO groups. It will initially concentrate on seven countries: The Gambia, Senegal, Mali, Burkina Faso, Niger, Sudan, and Ethiopia.

Jon Tinker, President

The Panos Institute

8 Alfred Place

London WCIE $7 E B$

England, $U K$. 